\title{
New records of suctorians (Ciliophora: Suctoria) as epibionts of aquatic true bugs (Hemiptera: Prosorrhyncha: Nepomorpha) from two regions: Mexico and Eastern Europe
}

\author{
RICARDO MARIÑO-PÉREZ ${ }^{1,3}$, IGOR DOVGAL ${ }^{2} \&$ ROSAURA MAYÉN-ESTRADA $^{1}$ \\ ${ }^{1}$ Laboratorio de Protozoología, Departamento de Biología Comparada, Facultad de Ciencias, UNAM, Ciudad Universitaria s/n, \\ 04510, Mexico City, Mexico \\ ${ }^{2}$ Schmalhausen Institute of Zoology, B.Khmelmitsky str., 15, 01601, Kiev, Ukraine \\ ${ }^{3}$ Corresponding author. E-mail: pselliopus@yahoo.com.mx
}

\begin{abstract}
Here, we provide new records of suctorians (Ciliophora: Suctoria), epibionts of aquatic true bugs (Hemiptera: Prosorrhyncha: Nepomorpha) collected in Ukraine, Belarus and Mexico. The worldwide distribution of the 16 species we found is updated, from which, 15 species are new records as epibionts of 15 species of aquatic true bugs. Only for the suctorian Discophrya gessneri Matthes, we confirm the previous record (epibiont of Aphelocheirus aestivalis Fabricius). We conclude that the relationship between the suctorians and aquatic true bugs is poorly studied and some suctorian genera (Discophrya Lachmann and Periacineta Collin) inhabit as nepomorphans as other aquatic insects (Coleoptera). However the high degree of specificity at the species level of these genera is evident, for which we provide some possible explanations according to the group of basibiont.
\end{abstract}

Key words: Suctorian, nepid, epibiosis, epibiont-basibiont system, Mexico, Ukraine, Belarus

\section{Introduction}

There are approximately 8,000 species of ciliated protozoa (Lynn, 2008), and some of them are symbionts of other organisms. Epibiotic suctorian ciliates of aquatic insects (such as hemipterans) are poorly understood worldwide, and few studies have been done for the genera Corixa Geoffroy, Sigara Fabricius, Notonecta Linnaeus, Plea Leach, Nepa Linnaeus, Naucoris Geoffroy and Aphelocheirus Westwood (Matthes et al. 1988). Recently in Mexico, Mariño-Pérez \& Mayén-Estrada (2009) recorded Discophrya elongata (Claparède et Lachmann) and Acineta tuberosa Ehrenberg as epibionts of the water boatman Corisella edulis (Champion). In the Ukraine, Dovgal $(1987,1991)$ reported Discophrya lichtensteinii (Claparède et Lachmann) (under synonym name D. wrzesniowskii) as an epibiont of the water scorpion Ranatra linearis (Linnaeus), D. ochthebii Matthes as an epibiont of the pygmy backswimmer Plea leachi McGregor \& Kirkaldy, D. gessneri as an epibiont of Aphelocheirus aestivalis, Periacineta buckei (Kent) (under name P. nepae) on the water scorpion Nepa cinerea Linnaeus, and Ranatra linearis and Periacineta notonectae (Claparède et Lachmann) as epibionts of the water boatman Corixa sp. Only two of these suctorians, Discophrya lichtensteinii and Periacineta buckei were recorded on Nepa cinerea, from Lake Khotin, highwater bed of river Desna, near village Timanovka, Sumy region (Dovgal, 1987). Also, Dovgal (1987, 1991) reported for the first time $D$. lichtensteinii and $D$. ochthebii as epibionts of true bugs.

The aims of the present study are to update and compare the records and distribution of epibiont suctorian attached to some aquatic insects, from two biogeographical areas. 


\section{Material and methods}

Between the years 1983-2010, several aquatic insects (hemipterans) were collected at certain localities in Ukraine, Belarus, and Mexico. The insects were collected with a $0.5 \mathrm{~mm}$ mesh net or by manual sampling and then, fixed and preserved with $70 \%$ alcohol or $4 \%$ formalin. For microscopical observation, the suctorian ciliates were recorded and identified, fixed with Bouin's fixative for $5 \mathrm{~min}$. and stained with either Heidenhain's or Boehmer's haematoxylin, or fixed with 70\% alcohol and stained with Harris' haematoxylin. According to Lynn (2008) the taxonomic status for each species of suctorian is presented. Here, we provide the aquatic true bugs species that carries the epibionts, the country and for some localities the geo-reference. Additional data such as altitude are given in meters above sea level (m.a.s.l.). We include for each species of suctorian cilate, a diagnosis and morphometrical data. We also compiled the available data about epibiont suctorians providing the previous records of the species and also previous measurements.

\section{Results}

We obtained 16 species of suctorians representing three subclasses, five orders, 10 families, and 11 genera. These protozoans were found attached to 15 species of aquatic true bugs representing 11 genera and seven families: Nepidae (Ranatra linearis, Nepa cinerea, Ranatra spp. Fabricius); Belostomatidae (Belostoma spp. Latreille, Lethocerus sp. Mayr); Naucoridae [(Naucoris cimicoides (Linnaeus), Ambrysus spp. Stål)]; Pleidae (Plea leachi); Corixidae [(Hesperocorixa laevigata (Uhler), Corixa sp.)]; Aphelocheiridae (Aphelocheirus aestivalis) and Notonectidae (Notonecta unifasciata Guerin-Meneville).

For Ukraine and Belarus, we found nine species as new records, and for Mexico we observed only three new records. Four species of suctorians were found distributed in all three countries (Ukraine, Belarus, and Mexico) as new records. The suctorian Periacineta buckei was found in ten species of aquatic true bugs, and Discophrya elongata was found in seven basibiont species. The nepomorphs which harboured the highest species richness, were the nepids Ranatra linearis (5 species), and Nepa cinerea (4 species).

\section{Systematics}

Species taxonomy (Lynn, 2008).

Class PHYLLOPHARYNGEA de Puytorac et al., 1974

Subclass Suctoria Claparède et Lachmann, 1858

Order Exogenida Collin, 1912

Family Podophryidae Bütschli, 1889

Genus Podophrya Ehrenberg, 1834

Species Podophrya fixa (O.F. Müller, 1786)

Family Metacinetidae Bütschli, 1889

Genus Metacineta Bütschli, 1889

Species Metacineta longipes (Mereschkowsky, 1877)

Family Manuelophryidae Dovgal, 2002

Genus Manuelophrya Matthes, 1988

Species Manuelophrya hannae (Guhl, 1985)

Order Endogenida Collin, 1912

Family Acinetidae Ehrenberg, 1838

Genus Acineta Ehrenberg, 1834

Species Acineta fluviatilis Stokes, 1885

Family Tokophryidae Jankowski, 1978

Genus Tokophrya Bütschli, 1889

Species Tokophrya quadripartita (Claparède et Lachmann, 1859)

Tokophrya lemnarum (Stein, 1859)

Family Dendrosomatidae Bütschli, 1889 
Genus Dendrosoma Ehrenberg, 1838

Species Dendrosoma radians Ehrenberg, 1838

Family Pseudogemmidae Jankowski, 1978

Genus Pseudogemma Collin, 1912

Species Pseudogemma pachystyla Collin, 1912

Order Evaginogenida Jankowski, 1978

Family Discophryidae Collin, 1912

Genus Discophrya Lachmann, 1859

Species Discophrya elongata (Claparède et Lachmann, 1859)

Discophrya gessneri Matthes, 1954

Discophrya lichteinsteinii (Claparède et Lachmann, 1859)

Discophrya ochthebii Matthes, 1954

Family Periacinetidae Jankowski, 1978

Genus Periacineta Collin, 1909

Species Periacineta buckei (Kent, 1882)

Periacineta notonectae (Claparède et Lachmann, 1859)

Genus Kormosia Dovgal, 2002

Species Kormosia linguifera (Claparède et Lachmann, 1859)

Family Heliophryidae Corliss, 1979

Genus Cyclophrya Gonnert, 1935

Species Cyclophrya magna Gonnert, 1935

\section{Suctorian species records}

\section{Family Podophryidae Bütschli}

Podophrya fixa (O.F. Müller, 1786)

Fig. 3c.

The cell is spherical, stalk long, thin, slightly bent. Numerous capitate tentacles, variable in length, equally spaced over the body surface. There is one centrally located, spherical macronucleus, and one contractile vacuole. Reproduction by pseudo-scissiparity producing a bud that is approximately a same size as a mother cell with about 12 longitudinal rows of cilia and several rudimentary tentacles (Curds, 1986). The stalked oviform cyst with four transversal ribs is characteristic for this species.

Dimensions (in $\mu \mathrm{m}$ ): body diameter 10-40; length of stalk 80-100; stalk diameter 4-5; macronucleus diameter 11-15; length of tentacles 12-25. Previous measurements: body diameter 25-70; length of stalk 35-140; length of tentacles until 120 .

Material examined. Found as epibiont of: Plea leachi. Ukraine. Small lake in high-water bed of Desna river near village Klad'kovka, Chernigov region, 12.07.1984.

Additional records. On Cambarus Erichson (Morado \& Small, 1995). On algae; seawater, wastewater; aquatic plants, copepods, sewage treatment plants (Matthes et al. 1988). On aquatic plants, copepod, sewage treatment plants (Aladro-Lubel et al. 2006). On Gammarus wilitzkii Birula (Fernandez-Leborans, 2009; FernandezLeborans et al. 2006).

\section{Family Metacinetidae Bütschli}

\section{Metacineta longipes (Mereschkowsky, 1877)}

Fig. 3e.

The cell is spherical or somewhat elongate, covered by stylotheca with very long stalk-like protuberance. Macronucleus is ovoid, centrally located. Cell body clamped to the stylotheca near the apical aperture. The apical aperture of stylotheca has 6 or 7 edges. Tentacles are long, clavate and arranged in 6 or 7 radial rows placed between edges 
of stylotheca (Rieder, 1985). Reproduction by semi-circumvaginative budding with generation of tomit in the partial invagination of trophont cortex.

Dimensions: body diameter 25-37; diameter of macronucleus 10-15; length of tentacles 30-50; stylotheca length 175-185; stylotheca width 40-50; stalk-like protuberance length 130-200. Previous measurements: body diameter 246; length (with stalk) 2,040.

Material examined. Found as epibiont of: Nepa cinerea. Belarus. River Ubort' near village Borovoe, 13.08.1983.

Additional records. On Lemna Linnaeus, Ceratophyllum Linnaeus (Matthes et al. 1988).
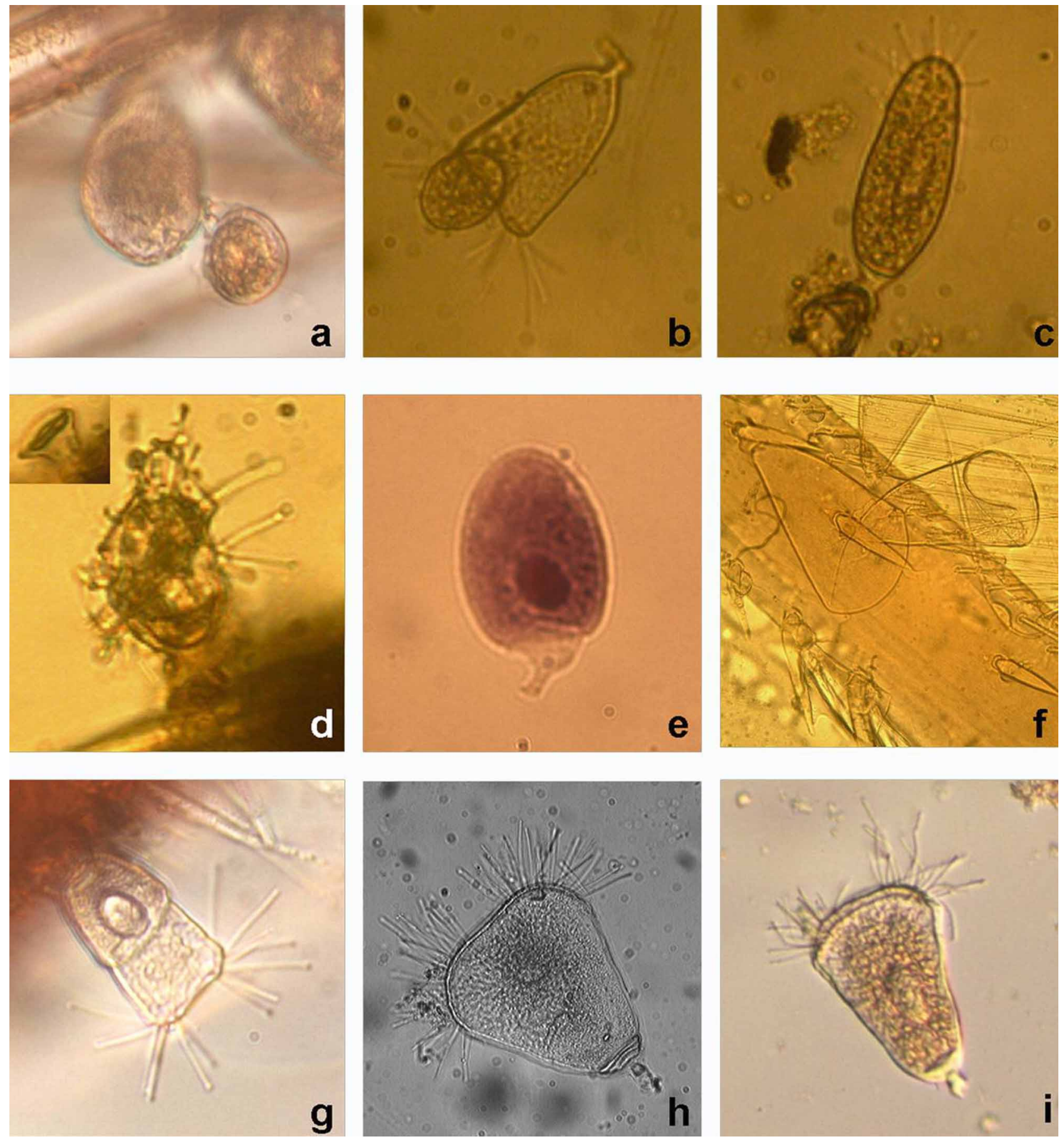

FIGURE 1. Some epibiotic suctorians of nepomorphans. a. Manuelophrya hannae parasite of peritrich epibiont of Lethocerus sp. (Mexico). b. Pseudogemma pachystyla parasite of Periacineta buckei attached to Ranatra sp. (Mexico). c. Discophrya elongata on Ranatra sp. (Mexico). d. Discophrya gessneri epibiont of Aphelocheirus aestivalis (Ukraine); the insert shows the shape of the stalk. e. Discophrya lichteinsteinii found on Ambrysus sp. (Mexico). f. Empty loricaes of Periacineta notonectae from Corixa sp. (Ukraine). g-i. Periacineta buckei from Ranatra sp., Belostoma sp. and Lethocerus sp., respectively (Mexico). 

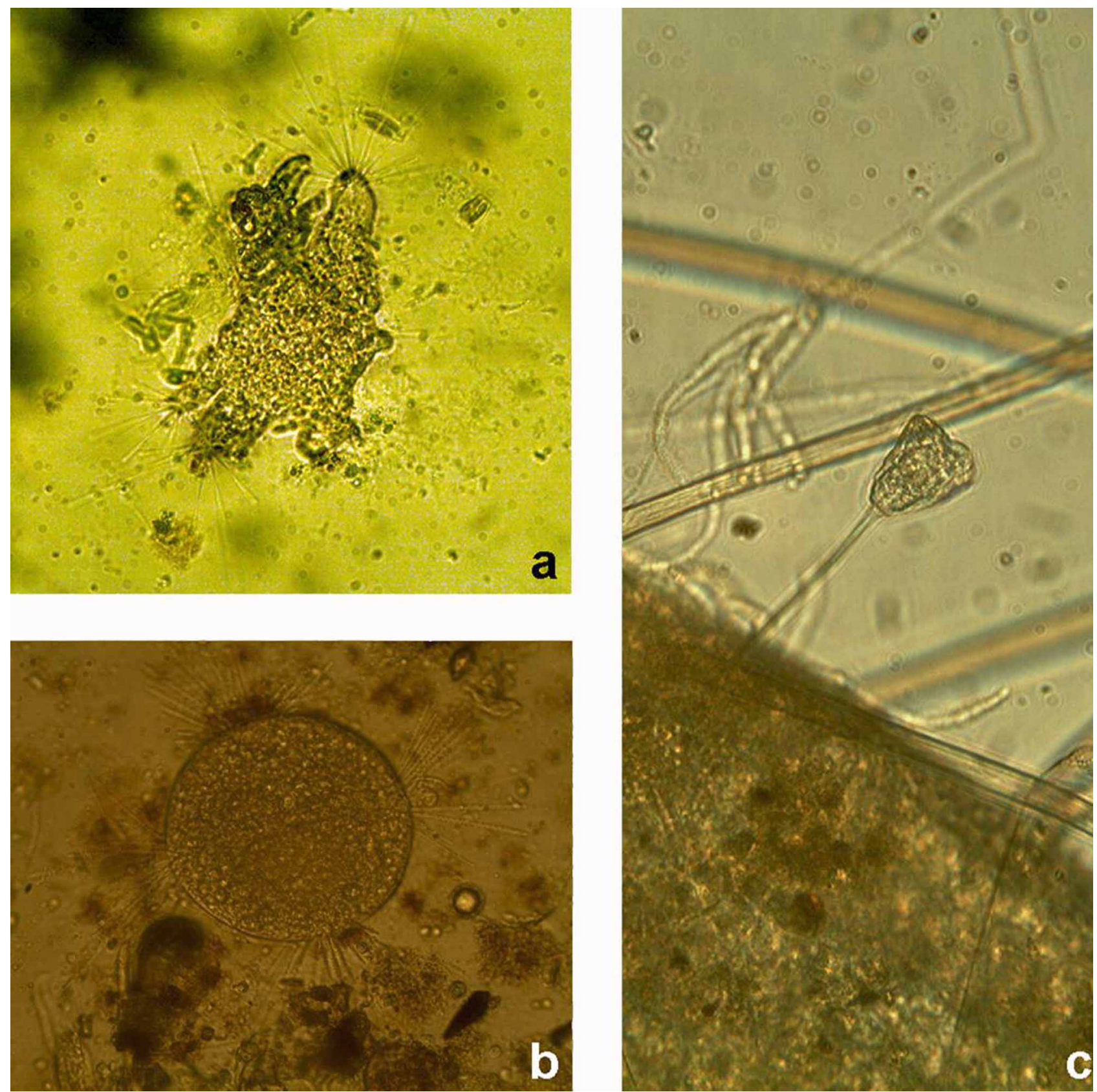

FIGURE 2. Some epibiotic suctorians of nepomorphans. a. Dendrosoma radians (Ukraine). b. Cyclophrya magna (Ukraine). c. Tokophrya lemnarum (Ukraine).

\section{Family Manuelophryidae Dovgal}

\section{Manuelophrya hannae (Guhl, 1985)}

Fig. 1a.

Cell is spherical with single, short, thick, rod-like tentacle by which this parasite of the peritrichs attaches to the host body. Lorica absent. Macronucleus spherical, centrally located. There are two contractile vacuoles, placed near the opposite site of the tentacular region of body. Reproduction by semi-circumvaginative budding.

Dimensions: cell body diameter 30-35; length of tentacles 15-20; diameter of macronucleus 8-12. Previous measurements: cell body diameter 30-35. 
Material examined. Found as ectoparasite of epibiont peritrich species from Lethocerus sp. Mexico. Near Grutas de la Estrella, Ixtapan de la Sal. State of Mexico. 1550 m.a.s.l. (18 ${ }^{\circ} 43^{\prime} 30.7^{\prime \prime}$ N; $99^{\circ} 35^{\prime} 59.1$ W). 18.09.2005.

Additional records. Ectoparasite of peritrich Haplocaulus walteri Precht (Matthes et al. 1988).

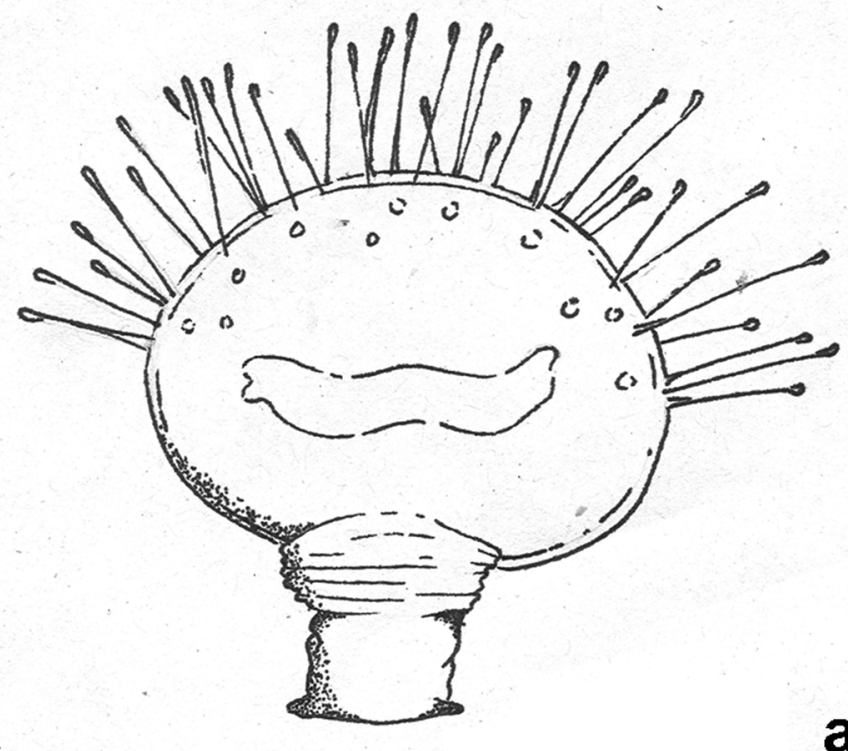

a

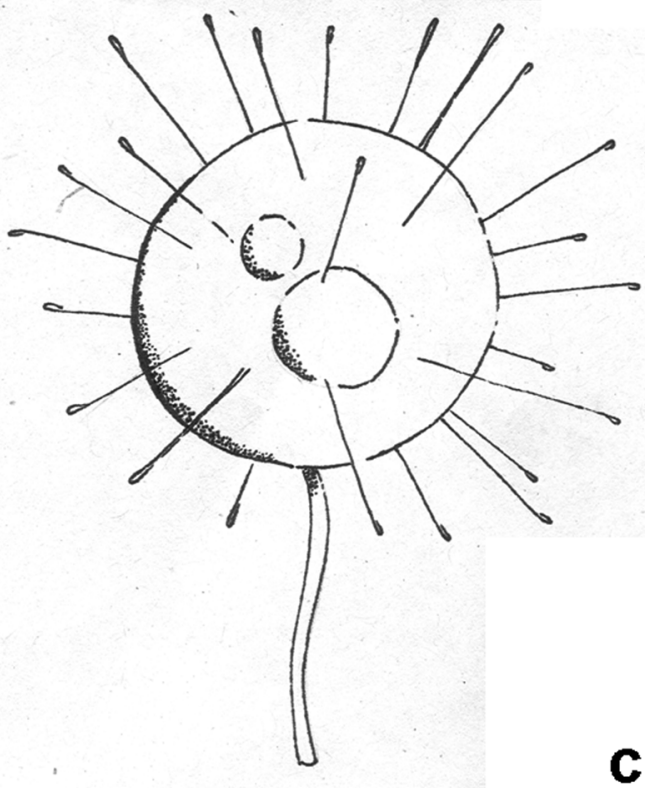

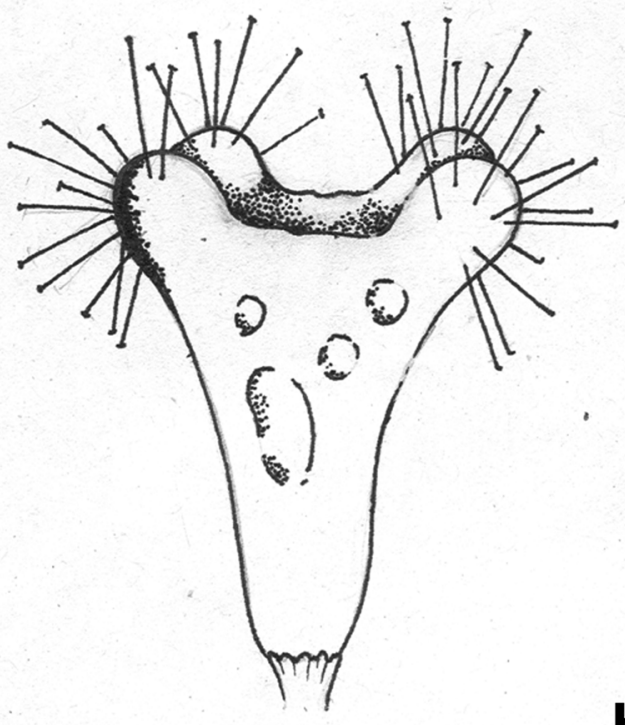

b

FIGURE 3. Some epibiotic suctorians of nepomorphans. a. Discophrya ochtebii. b. Tokophrya quadripartita from Lethocerus sp. (Mexico). c. Podophrya fixa. d. Kormosia linguifera. e. Metacineta longipes.

\section{Family Acinetidae Ehrenberg}

\section{Acineta fluviatilis Stokes, 1885}

Medium sized, freshwater, loricate species that is pyriform to triangular in outline, strongly compressed laterally. The apical aperture is slit-like through which the two fascicle born upon lobe-like actinophores protrude. Actinophores independently contractile. Stalk of variable length, joining with lorica without any collar or cup-like region. 
With centrally located spherical macronucleus and apical contractile vacuole. Reproduction by monogemmic endogenous budding (Curds, 1985a).

Dimensions: width of lorica 24-60; length of stalk 58-68; stalk diameter 5-7; macronucleus 10-14 x 15-45; length of the tentacles 18-30, diameter of contractile vacuole 6-8. Previous measurements: length 65 ; length of stalk 20-90.

Material examined. Found as epibiont of: Ranatra linearis. Ukraine. Small lake in high-water bed of Dnieper river (left bank) near Kiev, Ukraine. 08.01.1986. Horn of river Severskyi Donetc near village Cherkasskyj Bishkin', Kharkov region. 10.08.1989. Naucoris cimicoides. Ukraine. Pond at left bank of river Southern Bug near village Selyscshe, Vinnitca region. 19.08.1988.

Additional records. On Vallisneria spiralis Linnaeus (Curds, 1985a).

\section{Family Tokophryidae Jankowski}

\section{Tokophrya quadripartita (Claparède et Lachmann, 1859)}

Fig. 3b.

Species medium to large, freshwater whose body shape is pyramidal and approximately square in cross section. There are 4 lobe-like prominent actinophores, one at each corner of the apical surface, each bearing a fascicle of capitates tentacles. Lorica absent. Stalk of variable length present. Number of contractile vacuoles varies from 1 to 3. Macronucleus spherical to ovoid, centrally placed. There is one contractile vacuole. Endogenous budding results in an ovoid larval form with variable numbers of ciliary rows and formations (Curds, 1985b).

Dimensions: body length 50-138; body width 20-70; macronucleus 7-16 x 28-58; length of tentacles 20-50; length of stalk 80-220; stalk diameter 4-7. Previous measurements: body length $60-175$, body width $18-75$, length of tentacles until 90 .

Material examined. Found as epibiont of: Lethocerus sp. Mexico. Near Grutas de la Estrella, Ixtapan de la Sal. State of Mexico. 1550 m.a.s.l. (18 43' 30.7’ N; 99³ 35' 59.1 W). 18.09.2005.

Additional records. On aquatic plants, copepods, over stalk of Epistylis plicatilis Ehrenberg, on Asellus Geoffroy, Triturus sp. Rafinesque (Matthes et al. 1988); on Paludina Lamarck, Cyclops Müller, Chrysemys picta belli (Gray) (Curds, 1985b); on Cambarellus patzcuarensis Villalobos (Aladro-Lubel et al. 2006; Fernandez-Leborans, 2009). On Cyclops, Limnocalanus macrurus Sars, Epischura lacustris Forbes, Eucyclops agilis (Koch \& Sars), Cyclops bicuspidatus Claus, Astacus leptodactylus Eschscholtz (Fernandez-Leborans \& Tato-Porto, 2000). On Limnocalanus macrurus, Epischura lacustris and Asellus intermedius Forbes (Morado \& Small, 1995).

\section{Tokophrya lemnarum (Stein, 1859)}

Fig. 2c.

Freshwater species whose body shape is piryform to pyramidal. Lorica absent. Fascicles of capitate tentacles mounted on 2 actinophores. Stalk longitudinally striated, of variable length, but usually at least as long as body. There are usually 2 anterior-lateral contractile vacuoles. Macronucleus ovoid to elongate with several micronuclei. Reproduction by endogenous budding producing buds with 4 ciliary girdles (Curds, 1985b).

Dimensions: body length 30-48; body width 24-35; length of the tentacles 35-50; macronucleus diameter 912 ; stalk length $60-250$; stalk diameter 3-7. Previous measurements: body length $18-127$; body width $12-82$; stalk length 54-170.

Material examined. Found as epibiont of: Nepa cinerea. Ukraine. Pond near village Begun', Zhytomir region. 25.09.1984. Naucoris cimicoides. Ukraine. Small lake in high-water bed of river Western Bug near village Kamenka Bugskaya, Lvov region. 06.09.1985.

Additional records. On Lemna (Curds, 1985b); on aquatic plants, Asellus aquaticus (Linnaeus), Astacus leptodactylus, gammarids from Baikal lake (Curds, 1985b; Matthes et al.1988 ); on Gammarus Fabricius, Astacus leptodactylus (Morado \& Small, 1995); on Cordylophora caspia Pallas (Aladro-Lubel et al. 2006). 


\section{Family Dendrosomatidae Bütschli}

\section{Dendrosoma radians Ehrenberg, 1838}

Fig. 2a.

Suctorian ciliate with very large (up to $5 \mathrm{~mm}$ ) branched body. Several fascicles of tentacles placed at the numerous actinophores which are elevated over the substrate. Single macronucleus branched reaching the actinophores. Micronuclei are numerous. The shape of body is extremely variable depending on the type of substrate. Thus at the more or less flat substrate the individuals (especially young), have irregularly shaped flattened body with short, unramified actinophores, whereas on complex sufaces, i.e. aquatic invertebrates, the body might be dendritic with long branched actinophores. Reproduction by multiple endogenous budding.

Dimensions of individuals: body width 150-380; actinophore length 30-140; length of tentacles 10-30. Previous measurements: vertical length until 550; length of tentacles 75-90.

Material examined. Found as epibiont of: Ranatra linearis. Ukraine. Lake Lyubyaz' near village Lyubyaz' (high-water bed of Pripyat' river), Volyn' region, 08.06.1986. Aphelocheirus aestivalis. Ukraine. Psel river near village Kamennoe. 17.07.1988.

Additional records. On artificial substrate (Jones, 1974; Coats \& Clamp, 2009). On aquatic plants, Ceratophyllum, Callitriche Linnaeus, Elodea Michaux, Myriophyllum Ponted, algae, Cordylophora Allman, Phragmites Adanson, Polygonum Linnaeus, gammarids from Baikal lake (Matthes et al.1988); on Brandtia latissima (Gerstfeldt), Odontogammarus pulcherrimus Dorogostaisky, Pallasea cancellus (Pallas), Echinogammarus maacki Stebbing, Hyalellopsis czyrniankii Stebing (Fernandez-Leborans \& Tato-Porto, 2000).

\section{Family Pseudogemmidae Jankowski}

\section{Pseudogemma pachystyla Collin, 1912}

Fig $1 b$.

Ectoparasitic species with sacciform loricate body. There is single, short, thick, rod-like tentacle by which the parasite attaches to the apical part of the host (suctorian ciliates) body. The tentacle as a rule completely dipped into host cell body. Reproduction by endogenous budding.

Dimensions: body length 18-24; body width 16-20. Previous measurements: body length 20-30; body width $12-25$.

Material examined. Found as ectoparasite of Periacineta buckei, epibiont of: Ranatra sp. 1. Mexico. Tecocomulco lake. State of Hidalgo. 2530 m.a.s.l. (1952'30.5” N; 98²3'41.2” W). 15.09.2007.

Additional records. Brackish water from Béziers and the channel of the port of Cette; ectoparasite of Acineta tuberosa (Matthes et al. 1988).

\section{Family Discophryidae Collin}

\section{Discophrya elongata (Claparède et Lachmann, 1859)}

Fig. 1c.

Freshwater species whose body shape is elongate and flattened. Clavate tentacles are arranged in apical fascicle; with or without 2-5 lateral fascicles, or solitary lateral tentacles. Macronucleus varies from spherical to elongate. Stalk often longitudinal or transversal striated, and occasionally with apical cup-like broadening. There are from 3 to 6 contractile vacuoles. Reproduction by inversogemmic budding.

Dimensions: body length 17-101; body width 8.4-46; macronucleus 3-62 x 3-13; length of the tentacles 6-51; contractile vacuole diameter 3-7; length of stalk $8-102$; diameter of stalk 4-12. Previous measurements: body length 26-132; body width 17-48.

Material examined. Found as epibiont of: Ranatra sp. 1. Mexico. Tecocomulco lake. State of Hidalgo. 2530 m.a.s.l. (19 $52^{\prime} 30.5^{\prime \prime} \mathrm{N}$; $98^{\circ} 23^{\prime}$ 41.2” W). 15.09.2007. Ranatra sp. 2. Mexico. Near Grutas de la Estrella, Ixtapan 
de la Sal. State of Mexico. 1550 m.a.s.l. (18 43'30.7” N; 99 35' 59.1 W). 18.09.2005. Ranatra linearis. Ukraine. Small lake in high-water bed of Snov river near city Sednev, Chernigov region. 15.06.1991. Small lake in highwater bed of river Goryn' near village Zbuzh, Rovno region. 06.07.1985. Small lake in high-water bed of Dnieper river (left bank) near Kiev. 08.01.1986. Lake Lyubyaz' near village Lyubyaz' (high-water bed of Pripyat' river), Volyn' region. 08.06.1986. Small lake in high-water bed of river Teterev near village Charitonovka, Zhytomir region. 21.08.1986. Small lake in high-water bed of Dnieper river near village Liplyavo, Cherkassy region. 13.06.1998. Small lake in Kanev reserve, Cherkassy region. 10.06.1998. Belarus. Small lake in high-water bed of river Pripyat' near village Khojno, 14.06.1986. Ambrysus sp. 1. Mexico. Near Santo Domingo de Morelos. State of Oaxaca. 309 m.a.s.l. (15 52' 24.7” N; 96³7’ 49.6” W). 16.01.2009. Notonecta unifasciata. Mexico. Tecomatlán

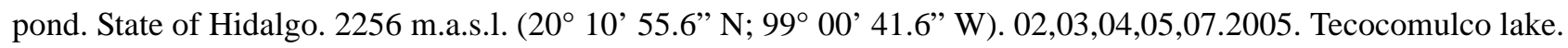
State of Hidalgo. 2530 m.a.s.1. (19 52 ' 30.5” N; 98 23' 41.2” W). 10.2006, 03,09,12.2007, 03.2008. Hesperocorixa laevigata. Mexico. Tecocomulco lake. State of Hidalgo. 2530 m.a.s.l. (195 52'30.5” N; 98 23' 41.2” W). 15.09.2007. Corixa sp. Ukraine. Goryn' river near village Duksin, Rovno region. 30.06.1985.

Additional records. On aquatic plants, Lymnaea Lamarck, Planorbis Mueller, Paludina, Nepa, Ranatra, Belostoma, Hydrous Thunberg, Dysticus Linnaeus, Cybister Curtis, Berosus Leach, and Tropisternus Solier (Matthes et al. 1988).

\section{Discophrya gessneri Matthes, 1954}

Fig. 1d.

Freshwater species with flattened asymmetrical body. Stalk short, cup-like apically covering about a quarter of body. Clavate tentacles not arranged in fascicles, evenly distributed over apical body surface and each one beginning from small projections of the cortex. Macronucleus spherical, centrally located. Reproduction has not been observed.

Dimensions: body length 20-42; width 17-36; length of the tentacles about 60 . Previous measurements: body length 18-38; body width 18-38; length of tentacles until 60.

Material examined. Found as epibiont of: Aphelocheirus aestivalis. Ukraine. Psel river near village Kamennoe. 17.07.1988. Psel river near village Malyj Perevoz, Poltava region. 24.07.1988. Belarus. Ubort' river between villages Kopishche (Zhytomir region, Ukraine) and Milashevichi (Gomel' region, Belarus) 12.08.1983.

Additional records. Aphelocheirus aestivalis (Matthes et al. 1988).

\section{Discophrya lichteinsteinii (Claparède et Lachmann, 1859)}

Fig. 1e.

Suctorian ciliate with flattened, disc-shaped or elongate body. Macronucleus ovoid, centrally located. Contractile clavate tentacles evenly distributed over all edge of body, but in some cases only at apical part. Stalk cup-shaped or elongate, with different length (Dovgal \& Kochin, 1997), uniformly expanding upwards, with transversal folds. There are up to three contractile vacuoles. Reproduction by inversogemmic budding.

Dimensions: body length 25-180; body width 15-160; macronucleus 5-7 x 12-16, stalk length 17-192; stalk diameter 4-7; length of the tentacles 6-28. Previous measurements: body length 29-180; body width 36-130.

Material examined. Found as epibiont of: Ranatra linearis. Ukraine. Small lake in high-water bed of Goryn' river near village Velyky Tceptcevichi, Rovno region. 11.07.1985. Small lake in high-water bed of river Goryn' near village Zbuzh, Rovno region. 06.07.1985. Plea leachi. Ukraine. River Unava near Fastov city, Kiev Region. 30.05.2004. Ambrysus sp. 2. Mexico. River Cuichat. State of Puebla. 980 m.a.s.l.. (2000’32” N; $97^{\circ} 30^{\prime} 46^{\prime \prime} \mathrm{W}$ ). 19.03.2010.

Additional records. On Cybister, Dysticus, Graphoderes Thomson, Haliplus Latreille, Peltodytes Régimbart, Brychius Thomson, Graptodytes pictus Fabricius, Hyphydrus ovatus Linnaeus, Coelambus impressopunctatus (Schaller), Hyphydrus Illiger, and Potamonectes elegans (Panzer) (Matthes et al. 1988). Aquatic coleopterans (families Dysticidae, Haliplidae) (Matthes et al. 1988). On Astacus Fabricius (Morado \& Small, 1995). 


\section{Discophrya ochthebii Matthes, 1954}

Fig. 3a.

Suctorian ciliate with flattened disk-like body, and cone-shaped short stalk with transversal ridges. Numerous long, clavate, contractile tentacles distributed over edge of body. Macronucleus spherical or ovoid, centrally located. A group (12-29) of contractile vacuoles placed near edges of body, or (when their number is greatest) thorough the body is characteristic. Reproduction by inversogemmic budding.

Dimensions: body length 26-50; body width 43-69; macronucleus 4-9 x 21-32; contractile vacuole diameter 3-4; length of tentacles 23-26; width of apical part of stalk 26-31. Previous measurements: body length 40-91; body width 43-124; length of stalk 9-45.

Material examined. Found as epibiont of: Plea leachi. Ukraine. Small lake in high-water bed of Psel river near mouth of Ol'shanka river. 16.07.1988. Former river-bed of Goryn' river near village Stavok, Rovno region. 04.07.1985. Small lake in high-water bed of Dnieper river (left bank) near Kiev. 07.08.1985. River Oster near city Nezhyn, Chernigov region. 17.09.1985. Small lake in high-water bed of Dnieper river (left bank) near Kiev. 24.11.1985. Lake Lyubyaz' near village Lyubyaz' (high-water bed of Pripyat' river), Volyn' region. 08.06.1986. Small lake in high-water bed of Pripyat' river near village Kopachi, (zone of Chernobyl' accident). 11.06.1987. Former river-bed of Psel river near village Vorozhba, Sumy region. 13.07.1988. Former river-bed of Psel river near village Sary, Poltava region. 21.07.1988. Small lake in high-water bed of Psel river near villages Perevoz and Savintcy Poltava region. 22.07.1988. Small lake in high-water bed of Severskij Donets river near village Cherkasskij Bishkin', Kharkov region. 10.08.1989. Small lake in high-water bed of Severskij Donets river near village Morozovka, Kharkov region. 11.08.1992. Small lake in high-water bed of Vorskla river near village Luchki, Poltava region. 07.07.1997. Small lake in high-water bed of Psel river near village Borovoe, Sumy region.11.07.1988.

Additional records. On aquatic coleopteran Ochthebius sp. Thomson (Matthes et al. 1988).

\section{Family Periacinetidae Jankowski}

\section{Periacineta buckei (Kent, 1882)}

Figs. 1g-i.

Polymorphic suctorian with trapeziform, flattened, loricate body. Lorica smooth, without transversal ribbons, and with slit-like aperture, the stalk is short. Macronucleus spheroidal or elongate. Tentacles are clavate, and capable to contract into body, and are arranged in two apical fascicles. Actinophores absent. There are from 1 to 4 contractile vacuoles. Reproduction by inversogemmic budding.

Dimensions: body length 16-120; width 19-59; macronucleus 13-38 x 4-7; contractile vacuoles diameter 2-4; length of the tentacles 8-75; stalk length 6-24; stalk diameter 3-10. Previous measurements: body length 24-450; body width 13-121; length of tentacles until 88 .

Material examined. Found as epibiont of: Belostoma sp. 1. Mexico. Tecocomulco lake. State of Hidalgo. 2530 m.a.s.1. (19 52'30.5” N; $98^{\circ} 23^{\prime}$ '41.2” W). 15.09.2007. Belostoma sp. 2. Mexico. Near Santo Domingo de Morelos. State of Oaxaca. 309 m.a.s.l. (15 52' 24.7” N; 96 37' 49.6” W). 16.01.2009. Belostoma sp. 3. Mexico. Near Grutas de la Estrella, Ixtapan de la Sal. State of Mexico. 1550 m.a.s.l. (18 43’30.7” N; 99 35' 59.1 W). 18.09.2005. Lethocerus sp. Mexico. Near Grutas de la Estrella, Ixtapan de la Sal. State of Mexico. 1550 m.a.s.l. ( $18^{\circ} 43^{\prime} 30.7^{\prime \prime}$ N; $99^{\circ} 35^{\prime}$ 59.1 W). 18.09.2005. Ranatra sp. 1. Mexico. Tecocomulco lake. State of Hidalgo. 2530 m.a.s.l. (19 $52^{\prime} 30.5^{\prime}$ N $; 98^{\circ} 23^{\prime} 41.2^{\prime \prime}$ W). 15.09.2007. Ranatra sp. 2. Mexico. Near Grutas de la Estrella, Ixtapan de la Sal. State of Mexico. 1550 m.a.s.l. (18 43'30.7” N; 99 35' 59.1 W). 18.09.2005. Ranatra linearis. Ukraine. Lake Lyubyaz' near village Lyubyaz' (high-water bed of Pripyat' river), Volyn' region. 08.06.1986. Small lake in high-water bed of Snov river near Sednev, Chernigov region. 15.06.1991. Small lake in high-water bed of river Goryn' near village Zbuzh, Rovno region. 06.07.1985. River Goryn' near village Stepan', 08.07.1985. Former river-bed of Desna river near sity Oster, Chernigov region. 21.09.1985. Small lake in high-water bed of Dnieper river (left bank) near Kiev, Ukraine. 08.01.1986. Belarus. Small lake in high-water bed of river Pripyat' near village Khojno, 14.06.1986. Nepa cinerea. Ukraine. River Snov near Village Gorsk, Chernigov region. 14.06.1991. River Zamglaj near village Kiselevka, Chernigov region. 10.07.1990. River Severskj Donetc near village Cher- 
vonaya Gorka, Kharkov region. 11.08.1989. Turya river near village Khoteshov, Volyn' region, 31.05.1986. Lake Svyatoe near village Zalukhov, Volyn' region. 04.06.1986. Ambrysus sp. 1. Mexico. Near Santo Domingo de Morelos. State of Oaxaca. 309 m.a.s.1. (15 52' 24.7” N; 96 37' 49.6” W). 16.01.2009. Naucoris cimicoides. Ukraine. Small lake in high-water bed of Psel river near village Staronovo. 12.07.1988.

Additional records. On artificial substrate (Jones, 1974; Coats \& Clamp, 2009). On Nepa, Ranatra, Naucoris, Hydrous, Helophorus Fabricius, Hydraena Kugelann, Argyoneta aquatica Clerck, and Planorbis (Matthes et al. 1988).

\section{Periacineta notonectae (Claparède et Lachmann, 1859)}

Fig. 1f.

Loricate suctorian species. Lorica stalked, slightly flattened, nearly conical, softly curved with wide apical aperture that have oblique cutted edge. Cell body fills up all lorica. Stalk very short and conical. Clavate tentacles are in two apical bundles. Actinophores absent. Macronucleus spherical. Reproduction by inversogemmic budding.

Dimensions: lorica length 113-137; width 45-52; macronucleus diameter 12-15; length of tentacles 30-42; length of stalk 12-18; stalk diameter 9-12. Previous measurements: body length 55-154; body width 29-74.

Material examined. Found as epibiont of: Hesperocorixa laevigata. Mexico. Tecocomulco lake. State of Hidalgo. 2530 m.a.s.l. (19 52'30.5” N; 98 23' 41.2” W). 15.09.07. Corixa sp. Ukraine. Irpen' river near village Irpen', Kiev region. 07.11.1998. Small lake in high-water bed of Psel river near mouth of Ol'shanka river. 16.07.1988. Pripyat' river near village Shchetyn', Volyn' region. 05.06.1986. Pripyat' river near village Pochapy, Volyn' region. 02.06.1986. River Zulnya near village Grushovka, Rovno region. 09.07.1985. Small lake in highwater bed of river Goryn' near village Zbuzh, Rovno region. 06.07.1985. River Zamchysko near mouth. 05.07.1985. Goryn' river near village Stavok, Rovno region. 07.07.1985. River Zarnovka near village Zhobryn, Rovno region. 30.06.1985. Goryn' river near village Duksin, Rovno region. 30.06.1985. Slovechna river near village Tkhorin, Zhytomir region. 30.09.1984. Pond near village Begun', Zhytomir region. 25.09.1984. Pripyat' river near village Bol'shye Soroki, Kiev region. 07.09.1984.

Additional records. On Notonecta, Corixa and Sigara (Matthes et al. 1988).

\section{Kormosia linguifera (Claparède et Lachmann, 1859)}

Fig. 3d.

Suctorian with triangular flattened body, with stylotheca provided by short stalk-like protuberance. There are two apical fascicles of contractile clavate tentacles. Macronucleus central and elongated. From 1 to 4 contractile vacuoles. Body attached to the lorica edges near aperture. Reproduction by inversogemmic budding.

Dimensions: lorica length 95-118; width 35-118; body length 67-84; macronucleus 13-17 x 31-38; length of tentacles 6-22. Previous measurements: body length 50-245; body width 40-130.

Material examined. Found as epibiont of: Ranatra linearis. Ukraine. Small lake in high-water bed of Goryn' river near village Velyky Tceptcevichi, Rovno region. 11.07.1985.

Additional records. Aquatic coleopterans (Coelambus Thomson, Hygrotus Stephens, Hydroporus Schellenberg, Graptodytes Seidlitz, Colymbetes Schellenberg, Berosus and Belostoma (Matthes et al. 1988).

\section{Family Heliophryidae Corliss}

\section{Cyclophrya magna Gonnert, 1935}

Fig. 2b.

Suctorian with large, flattened disc-shaped body. Macronucleus ribbon-like, convoluted, ramified. There are four (rarely five) bundles of long, contractile, clavate tentacles near the edge of body. There are from 4 to 8 contractile vacuoles. Reproduction by inversogemmic budding. 
Dimensions: diameter of body 90-108; length of tentacles 14-40. Previous measurements: diameter of body until 190; length of tentacles until 500.

Material examined. Found as epibiont of: Nepa cinerea. Ukraine. Snov river near village Gorsk, Chernigov region. 14.06.1991.

Additional records. Flowing water, slides (Matthes et al. 1988).

\section{Discussion}

The epibiotic relationship between suctorians and aquatic true bugs is poorly understood. There is little evidence of the degree of specificity in the epibiont-basibiont system. According to Hebsgaard et al. (2004), members of the infraorder Nepomorpha are well supported as a monophyletic group, with the Nepoidea (Belostomatidae and Nepidae) placed as the first branch clade. The next node corresponds to Corixidae as sister group of Tripartita (the rest of the families), whose relationship differs according to the analysis employed (morphological, molecular, combined) (Hebsgaard et al. 2004). According to previous and present data, the members of the superfamily Nepoidea present a higher diversity of epibiotic suctorians, with 11 species, nevertheless all the species of suctorians recorded in this subfamily have been previously found in substrates other than nepomorphans (i.e. aquatic coleopterans, crustaceans, and aquatic plants).

In contrast, in the most derived branches (Corixidae and Tripartita), the suctorian Discophyra gessneri has been recorded only as epibiont of Aphelocheirus aestivalis, and Periacineta notonectae has been found only as epibiont of members of the family Corixidae (Hesperocorixa laevigata, Sigara and Corixa sp.), and from only one genus of notonectid (Notonecta) (Claparéde et Lachmann, 1859). However, after careful revision through years of thousands of specimens of notonectids and corixids, we observed $P$. notonectae only in corixids, for which we consider this last record as a misidentification of the host. For these reasons we can catalogue this suctorian with a high specificity degree to corixids. Recently Mariño-Pérez et al. (2010) found a high specific suctorian (Periacineta mexicana Mariño-Pérez, Mayén-Estrada \& Dovgal) on species of the genus Buenoa Kirkaldy (Notonectidae). Nevertheless, we also recorded several species of non specific suctorians (i.e. P. buckei and D. elongata) in Corixidae and Tripartita.

Certain morphological and physiological features of the aquatic true bugs could rule the presence, specific richness, and or degree of specificity of epibonts over their body surface. For example, within the Nepoidea (Belostomatidae and Nepidae) there is a siphon for breathing air. Individuals are greater in comparison to the members of other families, but we do not find epibiotic ciliates species-specific (Schuh \& Slater, 1995). Species belonging to the family Notonectidae usually control their buoyancy capacity and use their abdominal setae to collect an air bubble; these actions reduce their movements through water column until they surface to obtain oxygen (Schuh \& Slater, 1995). Members of two families of aquatic true bugs, Naucoridae and Aphelocheiridae could use the plastron for oxygen uptake, so they can spend all the time submerged (Schuh \& Slater, 1995). In both cases, these actions probably favor the attachment of epibionts. Species of the family Corixidae are detritivorous and depend of active migrations through water column, for oxygen and food uptake. The rest of the families limit their displacement to prey capture due to predator habits. These behavior patterns could explain the high degree of specificity of Discophrya gessneri to be found upon Aphelocheirus aestivalis, Periacineta notonectae on corixids, and Periacineta mexicana on Buenoa spp. (Notonectidae).

\section{Acknowledgments}

We give thanks for the agreement between Universidad Nacional Autónoma de México and Schmalhausen Institute of Zoology, Ukraine, for a short term visit to Ukraine, and to CONACyT (Consejo Nacional de Ciencia y Tecnología) for providing scholarship \# 1875. The Posgrado en Ciencias Biológicas and Secretaría de Intercambio Académico, Facultad de Ciencias, UNAM, supported Dr. I. Dovgal for a short stay at UNAM, Mexico. We also want to thank Paul Tinerella (Illinois Natural History Survey), for his help in some nepomorphans identification. We also thank to M. C. Violeta Romero (Instituto de Geología, UNAM), for English improvement, to Biól. Itzel Sigala-Regalado (Facultad de Ciencias, UNAM) who provided some specimens of nepomorphans and to Silvia 
Hansen Bernal for the line drawings of figure 3. The comments of three anonymous referees substantially improved the final version of the manuscript.

\section{References}

Aladro-Lubel, M.A., Mayén-Estrada, R. \& Reyes-Santos, M. (2006) Registro actualizado de ciliados (agosto 2004). Listados faunísticos de México. Instituto de Biología, UNAM. Mexico, 97 pp.

Claparède, E. \& Lachmann, J. (1859) Etudes sur les Infusoires et les Rhizopodes. Memoires de l'Institut National Genevois, 6, 261-482.

Coats, D.W. \& Clamp, J.C. (2009) Ciliated Protists (Ciliophora) of the Gulf of Mexico In: Felder, D.L. \& Camp, D.K. (Eds.), Gulf of Mexico Origin, Waters and Biota Volume 1, Biodiversity. Texas A\&M University Press, pp. 57-79.

Curds, C.R. (1985a) A revision of the Suctoria (Ciliophora, Kinetofragminophorea). 1. Acineta and its morphological relatives. Bulletin of the British Museum (Natural History), 8(2), 75-129.

Curds, C.R. (1985b) A revision of the Suctoria (Ciliophora, Kinetofragminophorea) 3. Tokophrya and its morphological relatives. Bulletin of the British Museum (Natural History), 49(2), 167-193.

Curds, C.R. (1986) A revision of the Suctoria (Ciliophora, Kinetofragminophorea) 4. Podophrya and its morphological relatives. Bulletin of the British Museum (Natural History), 50(2), 59-91.

Dovgal, I.V. (1987) Ciliophora (Suctoria) of the Eastern part of Ukrainian Polesye area. Vestnik zoologii, 21(4), 3-8.

Dovgal, I.V. (1991) Peculiarities of Ciliophora Suctoria biocoenotic distribution in water bodies of the right-bank Ukrainian Polesje area. Vestnik zoologii, 25(4), 54-57.

Dovgal, I.V. \& Kochin, V.A. (1997) Fluid boundary layer as an adaptive zone for sessile protists. Zhurnal obshej biolohgii, $58(2), 67-74$.

Fernandez-Leborans, G. (2009) A review of recently described epibioses of Ciliate Protozoa on Crustacea. Crustaceana, 82(2), $168-189$.

Fernandez-Leborans, G. \& Tato-Porto, M.L. (2000) A review of the species of protozoan epibionts on crustaceans. II. Suctorian ciliates. Crustaceana, 73(10), 1205-1237.

Fernandez-Leborans, G., Arndt, C.E. \& Gabilondo, R. (2006) Protozoan epibionts and their distribution on the arctic ice-amphipod Gammarus wilkitzkii from Spitsbergen, Norway. Arctic, Antarctic, and Alpine Research, 38(3), 343-356.

Hebsgaard, M.B., Andersen, N.M. \& Damgaard, J. (2004) Phylogeny of the true water bugs (Nepomorpha: Hemiptera-Heteroptera) based on 16S and 28S rDNA and morphology. Systematic Entomology, 29, 488-508.

Jones, E.E. (1974) The Protozoa of Mobile Bay, Alabama. University of South Alabama Monographs No. 1, 113 pp.

Lynn, D.H. (2008) The Ciliated Protozoa. Characterization, Classification and Guide to the Literature. 3rd ed. Springer, Berlin, $605 \mathrm{pp}$.

Mariño-Pérez, R. \& Mayén-Estrada, R. (2009) Epibiotic relationship between two species of suctorians (Protozoa: Suctoria) and Corisella edulis (Hemiptera: Corixidae). Aquatic Insects, 31(3), 235-246.

Mariño-Pérez, R., Mayén-Estrada, R. \& Dovgal, I. (2010) Periacineta mexicana sp. n. (Ciliophora, Suctoria, Discophryida) Epizoic on Mexican Backswimmers of Genus Buenoa (Insecta, Hemiptera, Notonectidae). Journal of Eukaryotic Microbiology, 57(5), 435-443.

Matthes, D., Guhl, W. \& Haider, G. (1988) Suctoria und Urceolariidae (Peritrichia). Protozoenfauna Band 7/1. Gustav Fischer Verlag, Stuttgart, 309 pp.

Morado, J.F. \& Small, E.G. (1995) Ciliate Parasites and Related Diseases of Crustacea: A Review. Reviews in Fisheries Science, 3(4), 275-354.

Rieder, J. (1985) Critical revision of the literature and new communications of the genus Metacineta Bütschli (Protozoa, Suctoria) with proposal of a consequential taxonomy. Archiv fur Protistenkunde, 130, 201-287.

Schuh, R.T. \& Slater, J.A. (1995) True bugs of the World (Hemiptera: Heteroptera). Classification and natural history. Cornell University Press, Ithaca, $350 \mathrm{pp}$. 